\title{
A previously unknown disease of farmed Atlantic salmon: pathology and establishment of bacterial aetiology
}

\author{
R. Palmer, E. Drinan, T. Murphy \\ Aquatic Veterinary Group, BioResearch Ireland, University College Galway, Galway, Ireland
}

\begin{abstract}
A previously unknown disease of Atlantic salmon Salmo salar occurred on a seawater farm in Ireland, during 1992 and 1993. The gross pathology and the histopathology of the disease are described. A distinctive histological feature of the disease was the presence of intracellular Gramnegative bacteria in several tissues. In particular, the endothelial cells of the kidney glomeruli were enlarged and contained densely packed bacteria within cytoplasmic vacuoles. During later stages of the disease, most tissues showed numerous areas of necrosis surrounded by lymphoid cells. A bacterium was isolated on axenic media, and was demonstrated to be the causative agent by laboratory infectivity trials. The bacterium was approximately $0.4 \times 0.6 \mu \mathrm{m}$ in size in vivo, but also showed filamentous forms $(<5 \mu \mathrm{m})$ in vitro. In culture it was a slow-growing facultative or aerotolerant anaerobe requiring serum or blood for growth. It was not possible to characterize the organism by standard biochemical reactions, but additional characterization tests are in progress.
\end{abstract}

KEY WORDS: Atlantic salmon Pathology · Gram-negative bacterium - Intracellular

\section{INTRODUCTION}

During the period July to September 1992, a disease of unknown aetiology caused significant mortalities in Atlantic salmon Salmo salar on a seawater (SW) farm in Ireland. Losses in fish transferred to SW in 1990 and 1991 varied from $<1 \%$ to ca $60 \%$ per cage. Adjacent stocks of younger fish, transferred in April 1992, were apparently unaffected at this time. However, a further outbreak of the disease occurred on the site during March 1993, in the 1992 transfers, causing losses of $<1 \%$ to ca $5 \%$ per cage.

Water temperatures were 15 to $16^{\circ} \mathrm{C}$ and 8 to $9{ }^{\circ} \mathrm{C}$ during the first and second disease outbreaks, respectively. No obvious stress factors preceded the outbreaks. In both cases, oral administrations of oxytetracycline were accompanied by reductions in mortality rates.

Histological investigation of the disease indicated a systemic infection with an extracellular and intracellular Gram-negative bacterium. The bacterium was subsequently isolated in vitro and was demonstrated to be the causative agent by laboratory infectivity trials This report presents a description of the disease and evidence that the isolate was the aetiological agent.

\section{MATERIALS AND METHODS}

Fish. Fish were collected from the affected farm during the 2 periods of mortalities. Fish from outside those periods of overt infection, and from unaffected farms in the area, were also collected as part of routine health management programmes. Moribund and apparently healthy fish were sacrificed for gross, histological and microbiological examination. Tissues for microscopy were collected immediately after death. Kidney, spleen and liver tissues were removed aseptically and used for bacteriology or were stored at $-80^{\circ} \mathrm{C}$ for inoculation of cell lines.

Light microscopy preparations. Tissue samples were fixed in $10 \%$ buffered formalin, and $5 \mu \mathrm{m}$ wax sections were prepared. Tissue impressions and suspensions of bacterial cultures were air-dried and fixed 
with $70 \%$ ethanol or heat. Tissue sections, impressions and bacterial suspensions were stained by one or more of the following methods (Gurr 1963, Culling 1974): haematoxylin and eosin (H\&E), Gram, Ollett-GramTwort, Jensen-Gram, Sandiford-Gram, Lillie's allochrome (for periodic acid-Schiff reaction: PAS), Giemsa, Ziehl-Neelsen acid-fast, Proca-Kayser, Macchiavello, and Grocott-Gomori silver technique. Sections $(2 \mu \mathrm{m})$ in Spurr's resin were stained in toluidine blue.

Electron microscopy preparations. Selected wax embedded tissues were reprocessed for electron microscopy. Excised material was dewaxed in xylene, hydrated in aqueous ethanol (graded series), postfixed in $1 \%$ osmium tetroxide, dehydrated in acetone, and embedded in Spurr's resin. Uiltra-thin (470 nm) sections were stained with lead citrate and uranyl acetate and were viewed with a Hitachi 7000 transmission electron microscope.

Bacteriology. Swabs from kidneys, spleens and livers were initially inoculated onto a variety of bacteriological media (Difco Laboratories; Oxoid Ltd): brain heart infusion agar, marine agar, Mueller Hinton, cocarboxylase enriched Mueller Hinton (Bullock 1965), cytophaga agar (Anacker \& Ordal 1959), pseudomonas agar, selective kidney disease medium (SKDM; Austin et al. 1983), fastidious anaerobe agar, Lowenstein-Jensen media (with pyruvate and with glyceral), reinforced clostridial agar, thioglycolate medium with resazurin, marine agar with $10 \%$ foetal calf serum, brain heart infusion agar/broth with $10 \%$ foetal calf serum (BHIA-FCS, BHIB-FCS), $7 \%$ horse blood agar (HBA) and chocolate agar. All media were prepared with and without the addition of $1 \%$ sodium chloride $(\mathrm{NaCl})$. Incubations were at 15 and $22^{\circ} \mathrm{C}$, in aerobic conditions (plates sealed to maintain humidity), in $5 \% \mathrm{CO}_{2}$, and in anaerobic conditions, for up to $10 \mathrm{wk}$.

The primary isolate was aerobically maintained on HBA-NaCl, BHIA-FCS-NaCl or in BHIB-FCS-NaCl. Growth characteristics and biochemical reactions were determined according to standard procedures (Lennette et al. 1985, Finegold \& Baron 1986), but with $10 \%$ foetal calf serum and $1 \% \mathrm{NaCl}$ added to test media, and with extended incubation at $22^{\circ} \mathrm{C}$.

Spread plate counts were conducted on a BHIB-FCS-NaCl culture of the primary isolate; these were related to optical density (OD; at $540 \mathrm{~nm}$ ) determinations on the broth dilutions. OD determinations were used in some subsequent experiments for cell number estimates.

The primary isolate was tested for sensitivity to 4 antibiotics commonly used as fish therapeutants: oxytetracycline, oxolinic acid, cotrimoxazole (potentiated sulphonamide) and amoxycillin. Other antibiotics were also tested as an aid to characterization: penicillin G, vancomycin, kanamycin, erythromycin, polymyxin $B$ and colistin. Tests were performed by macro-broth dilution assays. Dilutions of antibiotics in BHIB-FCS- $\mathrm{NaCl}$ were inoculated with $10^{5}$ colonyforming units (CFU) $\mathrm{ml}^{-1}$. Growth was determined after 3 d at $22^{\circ} \mathrm{C}$, with the minimum inhibitory concentration (MIC) taken as the lowest concentration of drug giving complete inhibition of visible growth. The MICs were interpreted as showing sensitivity or resistance, according to human medical guidelines (National Committee for Clinical Laboratory Standards 1983).

Infectivity trials. Atlantic salmon $0+$ parr (mean weight $15 \mathrm{~g}$ ) were held in pathogen-free freshwater (FW) at $16^{\circ} \mathrm{C}$. Ten fish were injected intraperitoneally with the primary bacterial isolate: a $10^{8} \mathrm{CFU} \mathrm{\textrm {ml } ^ { - 1 }}$ BHIB-FCS-NaCl culture diluted to give $2.0 \times 10^{5} \mathrm{CFU}$ in a $0.1 \mathrm{ml}$ inoculum (spread plate count). BHIB-FCS-NaCl was used for the inoculum, as it had been previously found that washing and resuspending the culture in $2 \%$ $\mathrm{NaCl}$ caused a reduction in viability. Ten fish, injected with BHIB-FCS-NaCl and tail clipped, were introduced with the test fish as cohabitants. Moribund fish were sacrificed and their tissues collected for histology and bacteriology, or were allowed to die and used for bacteriology. The experiment was continued to Day 35 post-inoculation, when remaining fish were sacrificed for microbiological and histological examination.

Virology and bacterial infection of cell lines. Pooled kidneys, spleens and livers from 5 affected fish were homogenized (10\% suspension) in balanced salt solution, with and without antibacterials (penicillin 100 IU

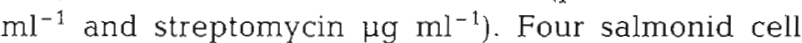
lines - rainbow trout gonad (RTG-2; Wolf \& Quimby 1962), Atlantic salmon embryo (AS; Nicholson \& Byrne 1973), chinook salmon embryo (CHSE-214; Lannan et al. 1984) and rainbow trout hepatoma (RTH-149; Fryer et al. 1981) - were inoculated with a 1:5 dilution of the homogenized tissue. Cultures were incubated at $15^{\circ} \mathrm{C}$ for $14 \mathrm{~d}$, with a blind passage for a further $14 \mathrm{~d}$.

Attempts were made to infect the above cell lines with the primary bacterial isolate. The cell culture media (without antibacterials) were inoculated with $10^{5} \mathrm{CFU} \mathrm{ml} \mathrm{ml}^{-1}$ of the organism in BHIB-FCS-NaCl, and were incubated and blind-passaged as described above.

\section{RESULTS}

\section{Clinical signs and gross pathology}

During the farm outbreaks, affected fish swam close to the surface, were lethargic and showed loss of balance. The fish appeared normal, except for small areas 
of erythema on the ventro-lateral skin, caused by salmon lice. Internally, in most affected fish, the abdominal walls showed petechiae or larger haemorrhagic areas (extending outwards from the peritoneum). Petechiae were present on the pyloric caeca, swimbladder and in all muscle bodies. The spleen and kidney were congested, with some splenomegaly and swelling of the kidney. The fore- and hind-guts contained white mucus. Other signs present in some affected fish were: a pale friable liver, a pale spleen, visceral adhesions, and false membranes in the peritoneum. Moribund fish were found occasionally with no gross lesions.

\section{Histopathology}

Numerous extracellular and intracellular bacterial cells were observed in spleen and kidney impressions. The bacterium was a small (ca $0.4 \times 0.6 \mu \mathrm{m}$ ) cocco-bacillus, and was Gram-negative, PAS-negative, weakly acid-fast, and stained with Giemsa, but did not stain with Macchiavello or Grocott-Gomori stains. Both the extracellular and the intracellular bacterial cells were Proca-Kayser-positive, indicating their viability.

In histologic sections from fish examined during the early stages of the outbreaks, the main changes were observed in the spleen and kidney.

The spleen was congested, with depletion of the lymphoid tissue. Some of the remaining lymphoid cells had pyknotic nuclei. There were necrotic changes in the endothelial cells of the splenic blood vessels. Macrophages containing large numbers of bacterial cells, as described, were present in the ellipsoids. The cell membrane in a number of macrophages had disrupted, releasing bacterial cells into the substance of the spleen. In some areas, due to their dense grouping and small size, the bacterial cells appeared as basophilic granular deposits in H\&E wax sections ( $5 \mu \mathrm{m})$, with individual cells discernible only in toluidine-blue-stained resin sections $(2 \mu \mathrm{m})$ or by electron microscopy.

The most common finding in the kidney was the presence of enlarged endothelial cells in the glomeruli, packed with basophilic granules (Fig. 1a). Examination of $2 \mu \mathrm{m}$ resin sections revealed these granules to be densely packed bacterial cells contained within large cytoplasmic vacuoles (Fig. 1b). Other kidney changes observed were oedema, debris in the lumina of collecting ducts, depleted haematopoietic tissue containing lymphoid cells with pyknotic nuclei, and macrophages with intracytoplasmic bacterial cells.

A number of hepatocytes scattered throughout the liver substance were vacuolated and undergoing necrosis. The endothelial cells lining the sinusoids were hypertrophied. There was also depletion and necrosis of the perivascular hepatic haematopoietic tissue

In the heart there were focal areas of vacuolation and myodegeneration in the trabecular muscle of the ventricle. The endocardial cells were hypertrophied and there was (in focal areas) a limited amount of subendocardial cell proliferation.

Gills showed focal telangiectasis and hyperplasia of the secondary lamellae, with low numbers of macrophages containing bacterial cells. Body flank muscles were congested and haemorrhagic, with limited lymphocytic infiltration.

During the later stages of the disease, in the haematopoietic tissue of the kidney there were multifocal areas of necrosis surrounded by necrotic haematopoietic blast cells, macrophages, and low numbers of lymphocytes, monocytes and neutrophils. Although these necrotic areas, or microabscesses, had no fibrotic reactions, they were clearly isolated from the normal tissues. Necrosis with no inflammatory response was present in some of the glomeruli. Numerous microabscesses, similar to those in the kidney, were present in the spleen (Fig. 2) and liver. Microabscesses were also observed within the focal areas of gill hyperplasia, the trabecular muscle of the heart ventricle, in the intestinal muscularis and in the pancreatic tissue.

\section{Electron microscopy}

The swollen granular cells, present in the glomeruli and spleen, were found to contain densely packed bacterial cells, of a size consistent with that noted above in the section 'Histopathology', within a membrane-bound cytoplasmic vacuole, surrounded by a thin envelope of the host cell cytoplasm and cell wall. The bacterium was shown to have a cell wall with a triple membrane, typical of Gram-negative bacteria (Fig. 3). Extracellular bacteria in the spleen and kidney tissues were shown to have a similar size and cell structure to those present intracellularly.

\section{Isolation of bacteria}

A bacterium with a distinctive colony type was isolated from the kidney, spleen and liver tissues of moribund fish from the affected farm, on media supplemented with horse blood or foetal calf serum (with the exception of SKDM), after 4 to $14 \mathrm{~d}$ incubation at 15 or $22^{\circ} \mathrm{C}$. Pure cultures of this bacterium were obtained 

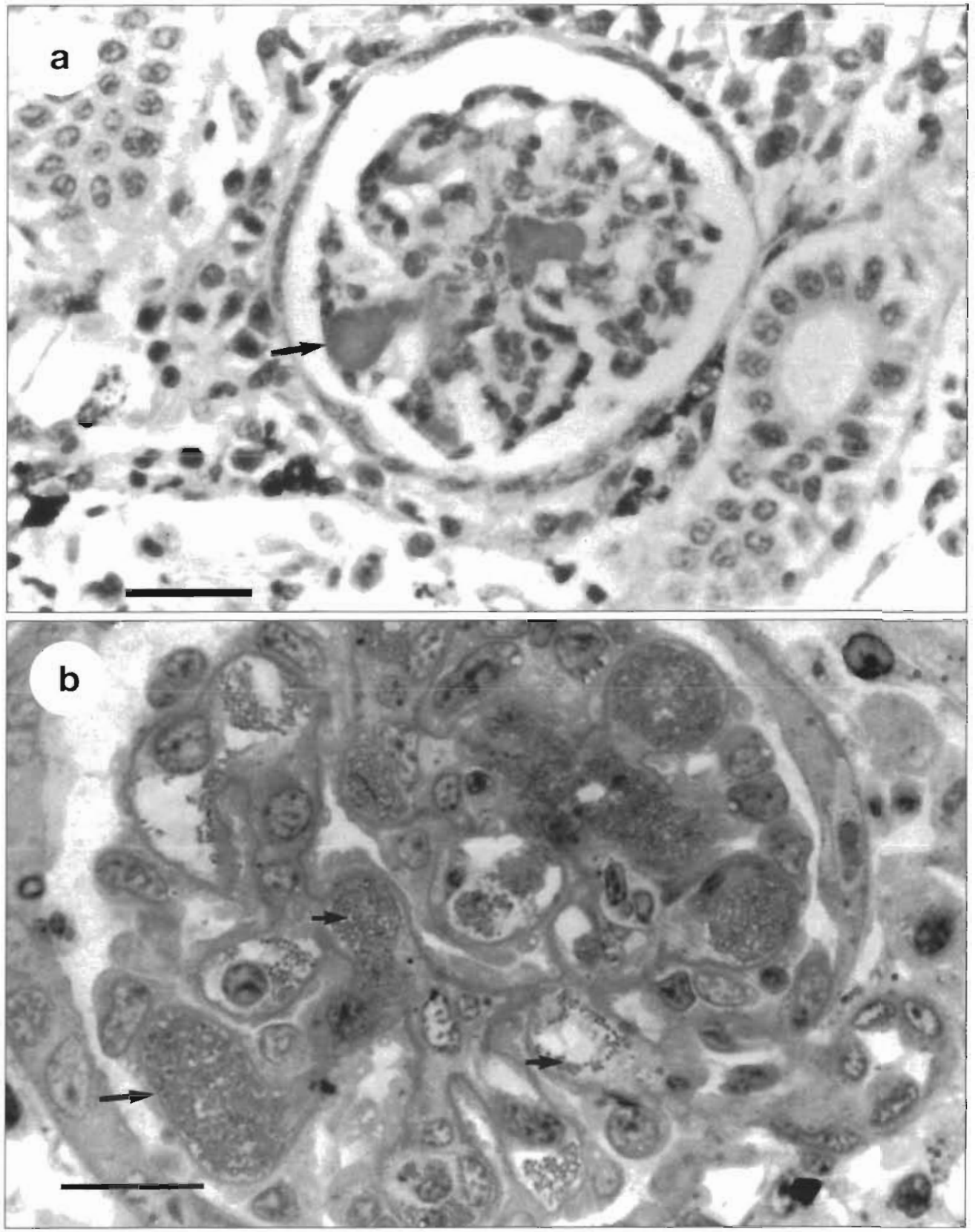

Fig. 1. Salmo salar. Kidney glomeruli of a moribund Atlantic salmon, with enlarged endothelial cells (long arrows) containing densely packed intracellular bacteria (short arrows). (a) Wax section, haematoxylin and eosin. Scale bar $=25 \mu \mathrm{m}$. (b) Resin section, toluidine blue. Scale bar $=12.5 \mu \mathrm{m}$

from approximately $70 \%$ of the moribund fish sampled, whereas approximately $30 \%$ gave mixed bacterial cultures. The mixed bacterial cultures grew on a number of media after 2 to $3 \mathrm{~d}$ incubation, and included Vibrio spp. and Pseudomonas spp. The noted bacterium was recovered from some of these mixed cultures by sub-culture on supplemented media. The bacterium was not isolated from apparently healthy fish from the same farm. Healthy fish, and fish with other disease conditions from nearby farms, were also negative for this organism.

\section{Characteristics of the primary bacterial isolate}

Growth of the isolate on solid media was most rapid on HBA-NaCl and BHIA-FCS-NaCl. On these media, small colonies (ca $0.1 \mathrm{~mm}$ ) were produced after 4 to $8 \mathrm{~d}$ incubation under aerobic conditions, at 15 and $22^{\circ} \mathrm{C}$. A maximum colony size of $0.3 \mathrm{~mm}$ was obtained after 10 to $14 \mathrm{~d}$ incubation. Incubation in an atmosphere of $5 \%$ $\mathrm{CO}_{2}$ did not improve growth within $14 \mathrm{~d}$, but incubation under anaerobic conditions produced a larger maximum colony size of $0.6 \mathrm{~mm}$. Colonies were off-white, 
Fig. 2. Salmo salar. Microabscess in spleen of a moribund Atlantic salmon, with a central eosinophilic area of necrosis. Haemotoxylin and eosin. Scale bar $=25 \mu \mathrm{m}$
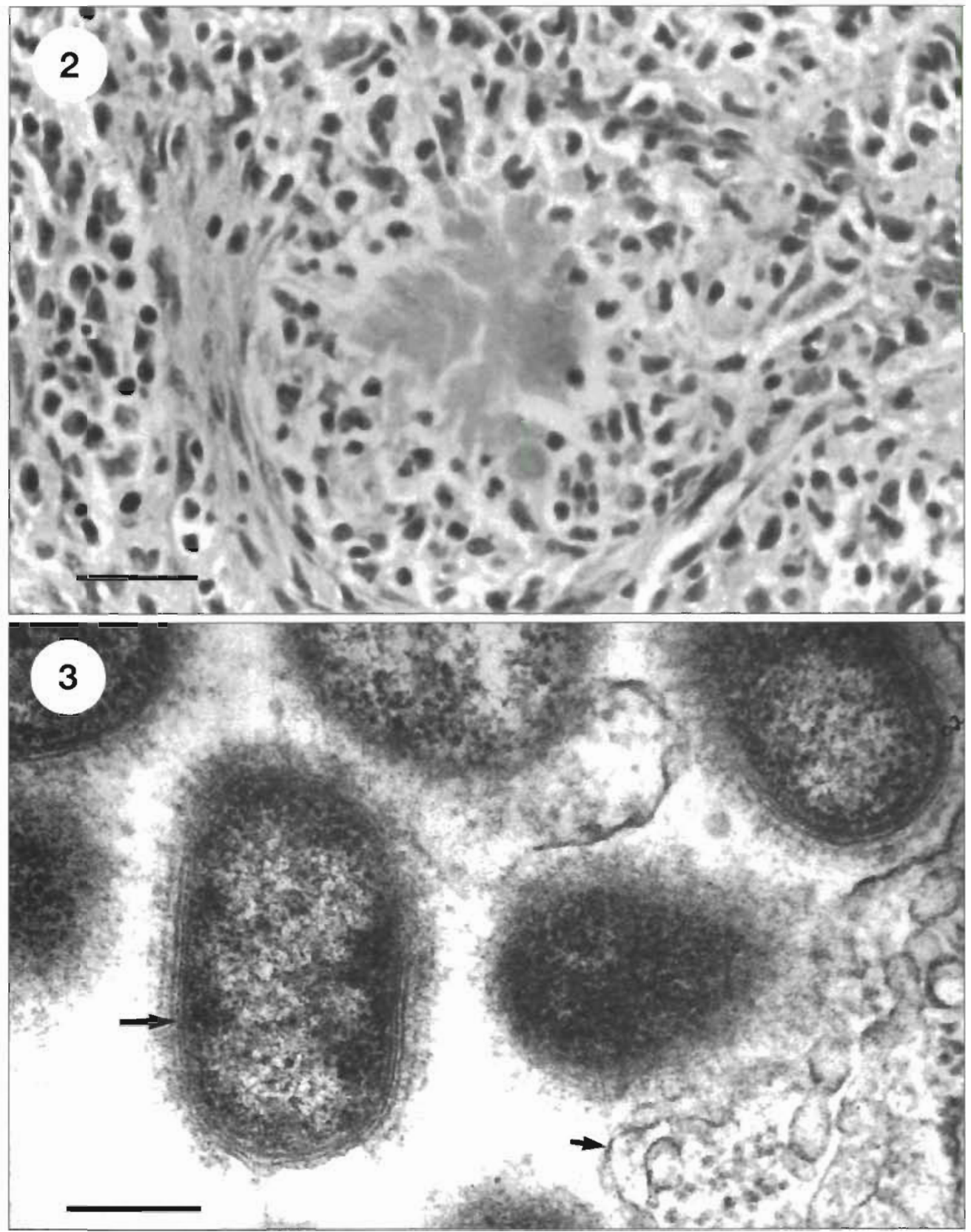

Fig. 3. Salmo salar. Intracellular bacteria, within a cytoplasmic vacuole of a kidney glomerula endothelial cell. Note membrane of cytoplasmic vacuole (short arrow) and triple-layered cell wall of bacterium (long arrow). Transmission electron microscopy, scale bar = $0.2 \mu \mathrm{m}$

above in the section 'Histopathology'. Older cultures, particularly in broths, additionally showed filamentous cells (ca $0.4 \mu \mathrm{m} \times<5 \mu \mathrm{m}$ ) with possible branching and occasional terminal swellings

Standard biochemical tests were difficult to perform due to the slow-growing and fastidious nature of the organism, and certain reactions were variable (indole, $\mathrm{H}_{2} \mathrm{~S}$ and alkaline phophatase) or slow to develop (Table 1). The bacterium was resistant to oxolinic acid, cotrimoxazole, polymyxin B and colistin, and was sensitive to all other antibiotics tested (Table 2). by light microscopy showed non-motile rods of the same size and staining characteristics as those noted friable, and initially had a convex, granular, 'breadcrumb' appearance, but later developed concave, 'molar tooth' patterns (Fig. 4). A small zone of $\beta$-haemolysi granular or flocculant growth occurred in broth culture (BHIB-FCS-NaCl). Growth was slightly improved by addition of L-cysteine $\mathrm{HCl}\left(0.5 \mathrm{mg} \mathrm{ml}^{-1}\right)$ to media, whereas cocarboxylase $\left(2 \mu \mathrm{g} \mathrm{ml}^{-1}\right.$ ) had no effect.

Examination of bacterial cells from young colonies 


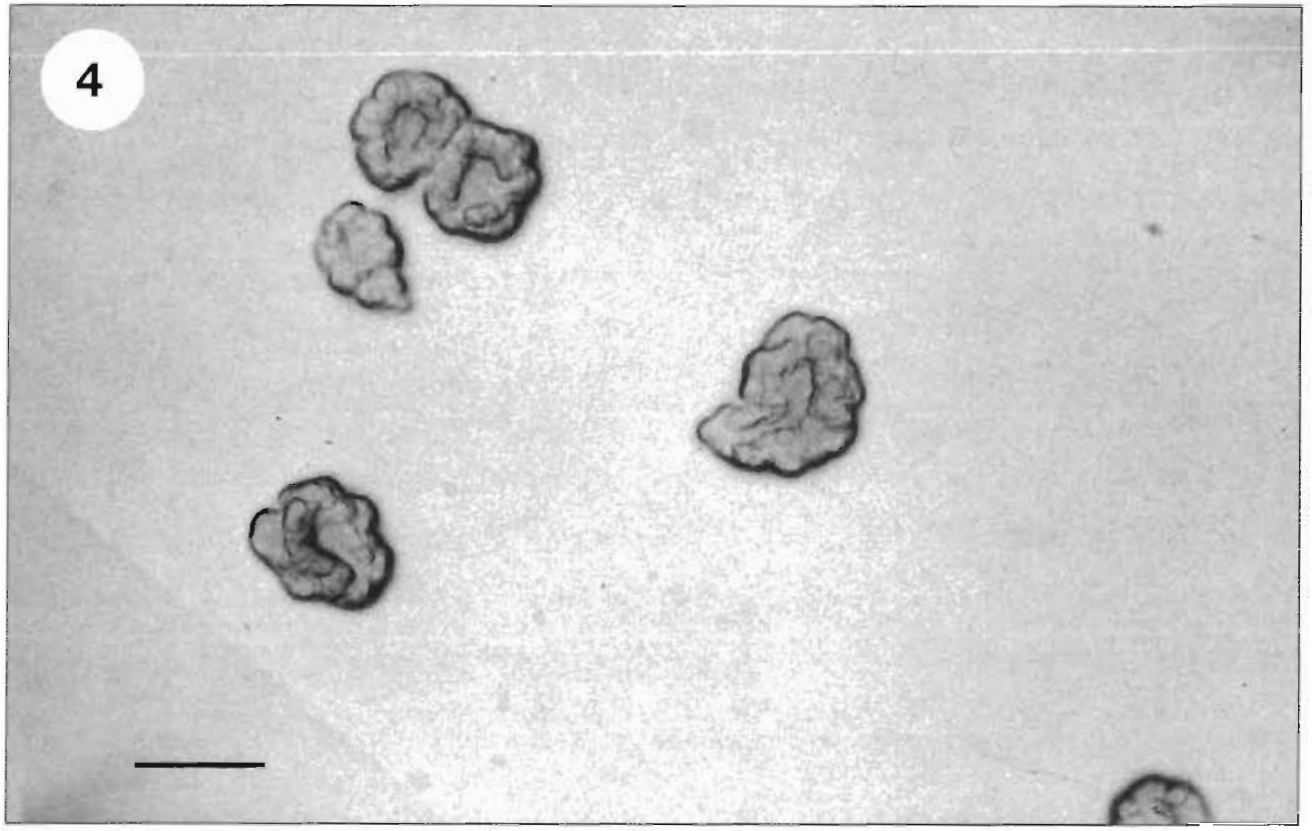

Fig. 4. Colonies of uncharacterized primary bacterial isolate from diseased Atlantic salmon Salmo salar, demonstrating typical 'molar tooth' appearance. Growth for $14 \mathrm{~d}$ at $22^{\circ} \mathrm{C}$, on supplemented brain heart infusion agar.

Scale bar $=0.25 \mathrm{~mm}$

\section{Infectivity trials}

Fish injected with the bacterium became moribund within 6 to $10 \mathrm{~d}$. Four moribund fish were removed for histology, 2 on each of Days 14 and 28. All the remaining injected fish died, over a period extending up to $30 \mathrm{~d}$ post-inoculation.

Moribund fish showed haemorrhagic areas in the jaw and cranial areas and at the base of fins. Haemorrhages were not observed in the body musculature; spleens and kidneys were pale and slightly swollen.

Histopathology was consistent with that found in the early phase of the natural disease. Particularly characteristic were the swollen glomerular endothelial cells, packed with basophilic granules which were shown by electron microscopy to be bacterial cells of size and cell structure consistent with those in the natural infection. Similar intracellular and extracellular bacterial cells were also present in the haematopoietic tissue of the kidney and spleen, and in the gills. Lesions in all tissues were as described for the early phase of the natural disease, although congestion in the spleen and congestion and haemorrhage in the body musculature were less extensive. There was no evidence of the tissue microabscesses described for the later phase of the natural disease.

The bacterium was re-isolated in pure culture from the kidneys of all 10 directly challenged fish. Cohabitant fish did not show signs of disease up to $35 \mathrm{~d}$, when. they were sacrificed for examination. All were negative for the bacterium by culture and histology.

\section{Virology and bacterial infection of cell lines}

No cytopathic effect (CPE) consistent with a viral or bacterial infection was obtained from inoculation of cell lines with tissue samples from affected fish.

Inoculation of cell lines with the primary bacterial isolate gave extracellular bacterial growth in the culture medium, but did not produce a CPE in the cell lines, and did not show intracellular bacterial infection

\section{DISCUSSION}

A Gram-negative bacterium was determined to be the causative agent of the disease described. The organism was a facultative or aerotolerant anaerobe, slow-growing, moderately halophilic, and required serum or blood for growth. The Gram-negative nature was established by the staining reactions and by the demonstration of a cell wall with a triple membrane. Further indications of the Gram-negative nature of the bacterium were given by the positive LANA and $\mathrm{KOH}$ tests, but the sensitivity to vancomycin was not typical for most Gram-negative groups (Carlone et al. 1983, von Graevenitz \& Bucher 1983). Some other antibiotic sensitivities were also atypical for many Gram-negative bacteria, in particular the resistances shown to polymyxin B and colistin (Lennette et al. 1985). The cell morphology and the slow-growing fastidious nature of the organism showed similarities to some members of the Pasteurellaceae (e.g. Actinobacillus 
rally infected tissue or axenic bacterial cultures. Infected tissues may have been inactivated by freeze storage, but axenic cultures had not been frozen, suggesting other reasons for failure to infect the cell lines. Specificity of the bacterium to certain host cell types, or absence of host chemical signals (antibodies, growth factors, lymphokines, etc.) may explain the non-infectivity for host cells in vitro (Moulder 1985). Further in vivo and in vitro examinations of the bacterium are required to investigate intracellular survival and replication.

Laboratory fish infectivity trials reproduced the main features of the natural disease, although some aspects of pathology differed. The parenteral administration of a high challenge dose may have resulted in a more acute form of the disease than in the natural infertion In particular, this was indicated by the lack of the chronic pathology found in the later phase of the natural infection. Non-transmission of the disease to the cohabitants may have been due to an insufficient period of challenge and incubation, a limited shedding of the organism by the inoculated fish and/or a low viability of the organism in FW. Alternatively, this finding may indicate that the natural route of transmission is not water-borne. Further transmission trials are in progress to determine the virulence level of the bacterium and the disease pathogenesis.

Acknowledgements. We particularly thank Margaret Ruttledge for her excellent assistance in histological and bacteriological preparations. We also thank the management and staff of the salmon farm, the Dept of Experimental Medicine UCG for provision of EM facilities, Kevin Callanan for assistance in tissue culture, and Prof. Frank Gannon for helpful advice.

\section{LITERATURE CITED}

Anacker, R. L., Ordal, E. J. (1959). Studies on the myxobacterium Chondrococcus columnaris I. Serological typing. J. Bacteriol. 78: 25-32

Austin, B., Embley, T M., Goodfellow, M. (1983). Selective isolation of Renibacterium salmoninarum. FEMS Microbiol. Lett. 17: 111-114

Brocklebank, J. R., Speare, D. J., Armstrong, R. D., Evelyn, I (1992). Septicemia suspected to be caused by a rickettsialike agent in farmed Atlantic salmon. Can. vet. J. 33: $407-408$

Responsible Subject Editor: T. Evelyn, Nanaimo, B.C., Canada
Bullock, G. L. (1965). Simple enrichment of a commercial medium for growth of Haemophilus piscium. Prog. Fish CuIt. 27. 163-164

Carlone, G. M., Valader, M. J., Pickett, M. J. (1983). Methods for distinguishing Gram-positive from Gram-negative bacteria. J. clin. Microbiol. 16 (6): 1157-1159

Culling, C. F. A. (1974). Handbook of histopathological and histochemical techniques, 3rd edn. Butterworths, London

Davies, A. J. (1986). A rickettsia-like organism from dragonets, Callionymus lyra L. (Teleostei: Callionymidae) in Wales. Bull. Eur. Ass. Fish Pathol. 6(4): 103-104

Finegold, S. M., Baron, E. J. (eds.) (1986). Bailey and Scott's diagnostic microbiology, 7 th edn. Mosby, St. Louis, MO

Fryer, J. L., Lannan, C. N., Giovannoni, S. J., Wood, N. D. (1992). Piscirickettsia salmonis gen. nov., sp. nov., the causative agent of an epizootic disease in salmonid fish. Int. J. syst. Bacteriol. 42(1): 120-126

Fryer, J. L., McCain, B. B., Leong, J. C. (1981). A cell line derived from rainbow trout (Salmo gairdneri) hepatoma. Fish Pathol. 15: 193-200

Gurr, G. T. (1963). Biological staining methods, 7 th edn. Baird and Tatlock, London

Lannan, C. N., Winton, J. R., Fryer, J. L. (1984). Fish cell lines: establishment and characterization of nine cell lines from salmonids. In Vitro 20: 107-114

Lennette, E. H., Balows, A., Hauser, W. J., Shadomy, H. J. (eds.) (1985). Manual of clinical microbiology, 4th edn. American Society for Microbiology, Washington, DC

McAllister, P. E., Herman, R. L. (1987). A chlamydia-like organism associated with high mortality in hatchery reared lake trout (Salvelinus namaycush). Fish Health Section, Am. Fish. Ass. Newslett. 15: 6

MacArthur, J. I., Fletcher, T C. (1985). Phagocytosis in fish. In: Manning, M. J., Tatner, M. F. (eds.) Fish immunology. Academic Press, London, p. 29-46

Moulder, J. W. (1985). Comparative biology of intracellular parasitism. Microbiol. Rev. 49(3): 298-337

National Committee for Clinical Laboratory Standards (1983). Standard methods for dilution antimicrobial susceptibility tests for bacteria that grow aerobically. M7-T. National Committee for Clinical Laboratory Standards, Villanova, PA

Nicholson, B. L., Byrne, C. (1973). An established cell line from the Atlantic salmon (Salmon salar). J. Fish. Res. Bd Can. 30: 913-916

Rodger, H. D., Drinan, E. M. (1993). Observation of a rickettsia-like organism in Atlantic salmon, Salmon salar, in Ireland. J. Fish Dis. 16(4): 361-369

von Graevenitz, A., Bucher, C. (1983). Accuracy of the KOH and vancomycin tests in determining the Gram reaction of non-enterobacterial rods. J. clin. Microbiol. 18(4): 983-985

Wolf, K. (1981). Chlamydia and rickettsia of tish. Fish Health News 10:1-5

Wolf, K., Quimby, M. C. (1962). Established eurythermic line of fish cells in vitro. Science 135: 1065-1066

Manuscript first received: April 27, 1993

Revised version accepted: January 31, 1994 